\title{
Vol. 506: 231-242, 2014 \\ Core habitat use of an apex predator in a complex marine landscape
}

\author{
Oliver J. D. Jewell ${ }^{1,2, *}$, Michelle A. Wcisel ${ }^{1,3}$, Alison V. Towner ${ }^{1,3}$, Wilfred Chivell ${ }^{1}$, \\ Lize van der Merwe ${ }^{4,5}$, Marthán N. Bester ${ }^{2}$ \\ ${ }^{1}$ Dyer Island Conservation Trust, Geelbek St, Kleinbaai, PO Box 72, Gansbaai, 7220, South Africa \\ ${ }^{2}$ University of Pretoria, Mammal Research Institute, Department of Zoology \& Entomology, Private Bag X20, Hatfield, \\ Pretoria, South Africa \\ ${ }^{3}$ University of Cape Town, Department of Zoology, Rondebosch 7701, South Africa \\ ${ }^{4}$ Division of Molecular Biology and Human Genetics, Faculty of Medicine and Health Sciences, Stellenbosch University, \\ Tygerberg, South Africa \\ ${ }^{5}$ Department of Statistics, University of the Western Cape, Bellville, South Africa
}

\begin{abstract}
Manual acoustic telemetry was used to describe core habitat use of white sharks in the complex marine landscape of the Dyer Island and Geyser Rock system near Gansbaai, South Africa. We compared home range estimates and swimming pattern analyses to those established at Mossel Bay, another white shark aggregation area roughly $300 \mathrm{~km}$ to the east. Traditional home range estimates used in Mossel Bay did not account for movement or barriers, and were thus biased towards areas with very little shark movement (i.e. potential resting areas). We found that adapting a Movement-based Kernel Density Estimate (MKDE) could account for movement and barriers, resolving these issues. At Dyer Island and Geyser Rock, daytime shark habitat use was adjacent to the seal colony, with low rates of movement, non-linear swimming patterns and small activity areas. At night, rates of movement and linearity increased as sharks travelled further from the islands into deeper waters. MKDEs revealed 4 focal areas of habitat use: a channel between the 2 islands, an area to the south of the seal colony, another area near a kelp feature to the southwest of the seal colony and a reef system to the northwest. These results differed significantly from the habitat use at Mossel Bay, where focal areas occurred adjacent to the seal colony during the hours of dawn and dusk. We discuss possible explanations for these differences. This study is the first to make use of MKDEs in a complex marine landscape and highlights important differences in habitat use of a threatened species between 2 separate aggregation areas.
\end{abstract}

KEY WORDS: White shark Carcharodon carcharias $\cdot$ Swimming patterns $\cdot$ Movement-based Kernel Density Estimate $\cdot$ MKDE $\cdot$ Acoustic telemetry $\cdot$ Utilization distribution

\section{INTRODUCTION}

Movement patterns often reveal core areas of habitat use that are crucial to species-specific life histories, such as breeding, feeding, nursery, nesting or pupping areas (Benhamou \& Cornélis 2010, Simpfendorfer et al. 2010, Cornélis et al. 2011). Focusing research in these areas that can be considered as temporary, site specific or seasonal ranges is crucial to conservation management strategies (Hearn et al. 2010, Heupel et al. 2010, Revuelta et al. 2012, Da Silva et al. 2013). By using movement data, home range estimates (first described by Burt 1943 and McNab 1963) have been used to define boundary lines for protected areas, reveal hotspots and areas of concern and inform policy makers on the effectiveness of management initiatives (Meyer \& Holland 2005, Hearn et al. 2010). 
Traditionally, animal home ranges are estimated by using location-based kernel density methods that build smooth histograms around positions (Worton 1989). These histograms, or Utilization Distributions (UDs), do not account for barriers or animal movement between positions. This creates UD estimates that are biased towards areas of aggregation and may include areas that are inconceivable (i.e. fish ranges over land) (Benhamou \& Cornélis 2010). Previous studies that estimated fish and shark home ranges have been forced to discard UD data that extend onto landscape boundaries such as islands, beaches, kelp forests and sandbars (e.g. Heupel et al. 2004, Weng et al. 2008, Domeier et al. 2012, Hammerschlag et al. 2012, Jewell et al. 2012). Additionally, UD estimates are likely to exclude navigation routes between focal areas of use, as in Jewell et al. (2012). These issues can be resolved by calculating a Movement-based Kernel Density Estimate (MKDE) that uses serially collected positions within an animal's track to estimate the UD (Benhamou \& Cornélis 2010, Benhamou 2011, Benhamou \& Riotte-Lambert 2012). MKDEs consider the time between positions and use movement to build the spatial density of the range, thus reducing bias in space use and habitat selection estimates (Benhamou \& Cornélis 2010). Furthermore, boundaries can be defined during analysis (Benhamou \& Cornélis 2010, Cornélis et al. 2011), making this approach particularly suitable for estimating UDs of marine animals.

Collecting enough movement data to calculate detailed home range estimates of predatory sharks is challenging, as these species are primarily pelagic and their populations have been drastically reduced due to extreme pressure from fisheries (Block 2005, Myers et al. 2007, Dulvy et al. 2008, Simpfendorfer et al. 2010, Speed et al. 2010, Block et al. 2011, Worm et al. 2013). The white shark Carcharodon carcharias is a good candidate for localised studies as it displays seasonal coastal site fidelity, often associated with pinniped colonies (Bruce 1992, Klimley et al. 2001, Bonfil et al. 2005, Hammerschlag et al. 2006, Johnson \& Kock 2006, Anderson et al. 2011, Domeier 2012, Domeier et al. 2012, Towner et al. 2013). Two studies have examined fine-scale habitat use of white sharks using active acoustic telemetry and home range analysis: Goldman \& Anderson (1999) at the Farallon Islands and Jewell et al. (2012) at Mossel Bay. Both studies found white sharks limited their movements within the aggregation sites and larger $(>400 \mathrm{~cm})$ sharks used significantly smaller ranges than smaller individuals (Goldman \& Anderson 1999, Jewell et al. 2012). Satellite telemetry with kernel analysis was used to examine fine-scale habitat use of white sharks at Guadalupe, Mexico (Domeier et al. 2012) and several studies have used passive acoustic telemetry to estimate residency times or foraging effort at seal colonies (i.e. Klimley et al. 2001, Johnson et al. 2009, Kock et al. 2013). Johnson et al. (2009) used both active and passive acoustic telemetry at Mossel Bay and found distinct diurnal patterns of habitat use, with white sharks approaching the seal colony at dawn and dusk and utilising reef systems during the day and night. The Dyer Island and Geyser Rock system has been identified as an important area of white shark aggregation in South Africa (Ferreira \& Ferreira 1996, Bonfil et al. 2005, Jewell 2013, Towner et al. 2013, Wcisel 2013), yet few telemetry studies and no regional home range estimates have been produced from the area prior to this study.

The marine landscape encompassing Dyer Island and Geyser Rock is complex, including islands, kelp forests, shallow reefs and rock pinnacles. Thus, this system is an ideal area to test the capabilities of the MKDE within channels and other heterogeneous features. We predicted that, by using manual acoustic telemetry, we would collect an adequate amount of fine-scale movement data for the parameters of the programme and that, by defining boundaries around Geyser Rock, Dyer Island and surrounding features, we would compute UDs more accurately than by using a traditional method. As our data collection is homologous with the methodology of Johnson et al. (2009) and Jewell et al. (2012), we also compare the spatial patterns of habitat use white sharks exhibit between this study site and Mossel Bay.

\section{MATERIALS AND METHODS}

\section{Study site}

Dyer Island and Geyser Rock are situated in the Western Cape Province of South Africa (Fig. 1). Geyser Rock hosts a year-round breeding colony of 55-60000 Cape fur seals (Dept. of Environmental Affairs unpubl. data). The 2 islands are separated by a narrow channel of shallow water 150 to $250 \mathrm{~m}$ across with a 6 to $7 \mathrm{~m}$ maximum depth known as Shark Alley (Wcisel 2013). A large reef system to the northwest (locally known as the Geldsteen) is connected to the islands by a dense kelp forest/shallow rock terrain, whilst the area to the south of Geyser Rock is characterised by deeper (15 to $25 \mathrm{~m}$ ) water. A shallow submerged peninsula of rock and kelp extends from Geyser Rock and terminates $400 \mathrm{~m}$ to 

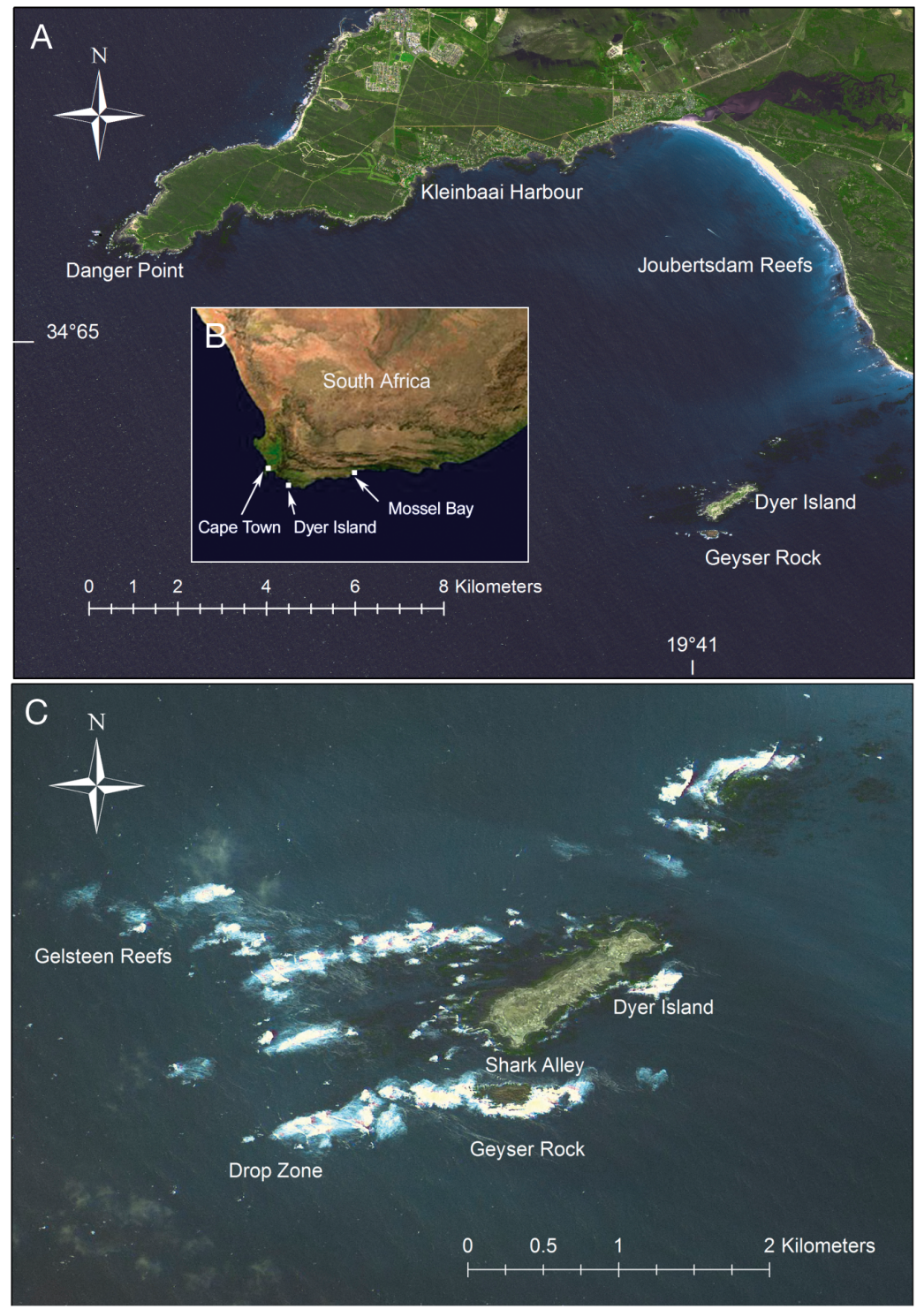

Fig. 1. (A,B) Position of study site. Dyer Island and Geyser Rock are located at approximately $34^{\circ} 68^{\prime} \mathrm{S}, 19^{\circ} 41^{\prime} \mathrm{E}, 200 \mathrm{~km}$ southeast of Cape Town, $300 \mathrm{~km}$ west of Mossel Bay and 9 km from Kleinbaai Harbour. (C) Geyser Rock, Dyer Island and adjacent area. White water indicates shallow reefs, ridges and kelp forest

the west at an area known as the Drop Zone. We consider these island features, the submerged penisular between Geyser Rock and the Drop Zone and the denser areas of kelp and rock joining the islands to the Geldsteen reef as barriers to white shark movements. Mossel Bay is situated approx. $300 \mathrm{~km}$ to the east of Dyer Island and Geyser Rock $\left(34^{\circ} 10^{\prime} \mathrm{S}\right.$, $22^{\circ} 10^{\prime} \mathrm{E}$ ) in the Indian Ocean. It is semi-enclosed and protected to the west. Seal Island hosts a Cape fur seal colony of 4500-5000 individuals (Dept. Environmental Affairs unpubl. data). The island is formed of a single rocky outcrop and has no surrounding kelp or prominent reef systems adjacent to it. Three reef systems found to the northeast of the island are considered to be important aggregation sites (Johnson \& Kock 2006, Johnson et al. 2009, Jewell et al. 2012).

\section{Tagging and tracking of sharks}

We used externally mounted, Vemco V-16TP (measuring temperature, $T$, and pressure [depth], P) ultrasonic continuous pingers (Voegeli et al. 2001) fitted with brush-tip heads. Both tags and tethers were coated with anti-fouling paint to reduce algal growth, which can interfere with performance of transmitters and increase drag (Jewell et al. 2011). Sharks were attracted to a research vessel using a baited line and a mixture of teleost products and sea water (chum) (Strong et al. 1992; see Supplement at www.int-res.com/articles/suppl/m506 p231_supp.pdf). We approximated shark total length (TL) by comparing the shark to the known dimensions of the vessel, further calibrations of estimates could be made if the shark was observed during later sampling trips (see Supplement for more details). We used a pole with a spear-tip head to insert the tag head into the base of the first dorsal fin. Once tags were placed, tracking protocol was set up in a similar method to those described in Johnson et al. (2009) and Jewell et al. (2012). Sharks were manually tracked using a boat based VR100 with a VH110 (50 to $85 \mathrm{kHz}$ ) directional hydrophone and at a minimum distance of 20 to $40 \mathrm{~m}(80 \mathrm{~dB})$ so as not to interfere with shark movements (Johnson et al. 2009). We could not correct positions as in Heithaus et al. (2002) due to an equipment failure.

We recorded boat-mounted GPS positions by hand every $5 \mathrm{~min}$. If the signal could not be received (e.g. due to an obstruction), recordings resumed upon reception of the next signal. The methods of tagging and tracking were approved and permitted by the Department of Environmental Affairs, Oceans and Coasts. 


\section{Data analysis}

We calculated Rate of Movement (ROM, a measurement of how far the shark was moving over time), Linearity Index (LI, an index of how straight the shark was swimming), Index of Reuse (IOR, an index of how much activity areas overlap from one day/ track to the next), activity areas from Minimum Convex Polygons (MCP, total area the shark used), discovery curves (total area use over time) and locationbased kernels (traditionally used to spatially define home ranges) using the same methods as Johnson et al. (2009) and Jewell et al. (2012), to afford direct comparisons to their studies from Mossel Bay (see Supplement for more details). Additionally, we calculated distance from Geyser Rock for each position and MKDEs using the methods described below. ROM, LI and distance from Geyser Rock were determined for each 5 min position, whereas IOR and activity area were determined from each track and UD estimates from an individual's total tracking data.

\section{Distance from Geyser Rock}

We measured the distance of each position from Geyser Rock with the measuring tool in ArcMap 10 as a way to assess temporal foraging patterns. Cape fur seals utilise kelp forests to the northwest and west of Dyer Island and Geyser Rock as refuge habitats during periods of high white shark presence (M. Wcisel, A. de Vos \& J. O'Riain unpubl.). Therefore, we included these kelp areas as extensions of the Geyser Rock system in our analysis as they are also foraging areas.

\section{Home range analysis}

We calculated traditional location-based kernel estimates with the animal movement tool on Arc 3.2, using Least Squares Cross Validation (LSCV) smoothing parameters (as in Jewell et al. 2012). Next, the Pascal programme described in Benhamou \& Cornélis (2010), Benhamou (2011) and Benhamou \& RiotteLambert (2012) was used to compute MKDE Utilisation Distributions (UDs). We first computed a diffusion coefficient $(D)$ of roughly 1000 for each shark, using the Biased Random Bridges (BRB) method in the programme (Benhamou 2011). We selected a $H_{\min }$ (minimum smoothing parameter in meters) of 50, as boundary length cannot be in excess of $3 \times H_{\min }$ or sharper than $90^{\circ}$. This gave us minimum boundary lengths of
$150 \mathrm{~m}$, enough to incorporate Geyser Rock and the kelp ridges to its west without excluding any of the tracked movement in the adjacent waters. The second boundary was around Dyer Island and thick kelp to its west. $L_{\min }$ (the length threshold of movement in meters, i.e. any movement of less than this is considered to be resting) was set to 10 . Once MKDEs were projected, they were imported into Arc GIS 10 for display and spatial analysis. Areas were calculated from 95 and $50 \%$ isobars. Full instructions on how to download and use the programme are available free and directly from S. Benhamou at www.cefe.cnrs.fr/ecologiecomportementale/simon-benhamou and the pascal programme can be freely downloaded from www. freepascal.org. For further details on the settings of the programme, see Supplement.

\section{Statistical analysis}

We used linear mixed-effects models for each of the outcomes: distance from Geyser Rock, ROM, LI, IOR and MCP per track in terms of all factors (time of day, sea state, size [TL] and shark ID) and some interactions between factors. Where necessary, the outcomes were transformed to approximate normality by adding a constant and taking the natural log. We used a random effect to account for the correlation between repeated measures on the same shark in all models. In some models, a random effect for different times of day (daytime, night) was nested inside the random effect for each shark. This enabled us to account for the correlation between the measurements of the same time on a specific shark. If the factors were not statistically significant after including all others in the model, we removed them (stepwise selection). The time taken to tag or locate a tagged shark resulted too few dawn observations (sharks tracked half an hour either side of sunrise) being made to include in the model. There were also limited dusk observations (sharks tracked half an hour either side of sunset) and their results were imprecise so these are not reported.

All p-values and estimated effects sizes reported were derived from these joint models. When effects were not statistically significant, they are not reported. Correlations and estimates of variance components from random effects are not reported. The modelling was done with functions from base $\mathrm{R}$ and from $\mathrm{R}$ package nlme, freely available from www. r-project.org. Mapping figures were produced from ArcMap 10 or ArcGIS 3.2; other figures were produced from R or Sigma Plot. 


\section{RESULTS}

Results were derived from 2214 data points from $220 \mathrm{~h}$ of manual acoustic tracking of 5 individual white sharks, with the majority of tracking taking place at reefs to the west of Dyer Island (Geldsteen), off the kelp ridge to the southwest of Geyser Rock (Drop Zone), areas south of Geyser Rock, a channel between Geyser Rock and Dyer Island (Shark Alley) and reefs to the east of Dyer Island (Table 1, Fig. 2).
Heavy fog (Shark 1), an equipment failure and crew injury occurring in the evening (Shark 3) meant that only 3 of the sharks were tracked during night hours (Sharks 2, 4 and 5).

Daytime movements were often limited to small activity areas close to the Geyser Rock system or Dyer Island (mean average daytime activity areas = $0.67 \mathrm{~km}^{2}$ ), with entire days being recorded in areas such as Shark Alley or directly adjacent to the islands and surrounding kelp forests. There were occasional

Table 1. Tracking results of 5 sharks tagged and tracked at Geyser Rock and Dyer Island from 26 January 2011 to 21 March 2012. Average values are given for each parameter per tracking period and an average for each individual shark's total

tracking duration. MKDE: Movement-based Kernal Density Estimates, IOR: Index of Reuse, ROM: Rate of Movement

\begin{tabular}{|c|c|c|c|c|c|c|c|c|c|c|c|c|}
\hline $\begin{array}{l}\text { Shark } \\
\text { ID }\end{array}$ & $\begin{array}{l}\mathrm{TL} \\
(\mathrm{cm})\end{array}$ & Sex & Track & Start date & $\begin{array}{l}\text { Dura- } \\
\text { tion } \\
\text { (h) }\end{array}$ & $\begin{array}{l}\text { Dist- } \\
\text { ance } \\
(\mathrm{km})\end{array}$ & $\begin{array}{l}\text { Area } \\
\left(\mathrm{km}^{2}\right)\end{array}$ & $\begin{array}{r}\mathrm{MK} \\
95 \% \\
\left(\mathrm{~km}^{2}\right)\end{array}$ & $\begin{array}{l}\mathrm{XDE} \\
50 \% \\
\left(\mathrm{~km}^{2}\right)\end{array}$ & IOR & $\begin{array}{c}\mathrm{ROM} \\
\left(\mathrm{m} \mathrm{s}^{-1}\right)\end{array}$ & $\begin{array}{c}\text { Linearity } \\
\text { index }\end{array}$ \\
\hline $\mathrm{S} 1$ & 320 & $\mathrm{~F}$ & $\begin{array}{c}1 \\
2 \\
3 \\
4 \\
5 \\
6 \\
7 \\
8 \\
9 \\
10 \\
11 \\
12 \\
\text { Total }\end{array}$ & $\begin{array}{l}\text { 26-Jan-11 } \\
\text { 27-Jan-11 } \\
\text { 29-Jan-11 } \\
\text { 30-Jan-11 } \\
\text { 30-Jan-11 } \\
\text { 31-Jan-11 } \\
\text { 04-Feb-11 } \\
\text { 05-Feb-11 } \\
\text { 13-Feb-11 } \\
\text { 16-Feb-11 } \\
\text { 02-Mar-11 } \\
\text { 03-Mar-11 }\end{array}$ & $\begin{array}{r}10.2 \\
4 \\
3.4 \\
1.4 \\
3.4 \\
1.3 \\
4.4 \\
4.4 \\
7 \\
4.3 \\
4.2 \\
6 \\
55\end{array}$ & $\begin{array}{r}13.07 \\
4.93 \\
3.93 \\
1.18 \\
7.12 \\
0.70 \\
4.04 \\
11.97 \\
6.97 \\
6.73 \\
3.82 \\
6.74 \\
71.20\end{array}$ & $\begin{array}{l}3.02 \\
0.10 \\
0.15 \\
0.02 \\
1.38 \\
0.03 \\
0.17 \\
2.30 \\
0.43 \\
0.16 \\
0.16 \\
0.21 \\
9.18\end{array}$ & 1.68 & 0.29 & $\begin{array}{l}0.09 \\
0.28 \\
0.18 \\
0.09 \\
0.14 \\
0.05 \\
0.34 \\
0.12 \\
0.16 \\
0.42 \\
0.31 \\
0.40 \\
0.23\end{array}$ & $\begin{array}{l}0.39 \\
0.54 \\
0.30 \\
0.18 \\
0.74 \\
0.14 \\
0.28 \\
0.75 \\
0.30 \\
0.43 \\
0.61 \\
0.33 \\
0.39\end{array}$ & $\begin{array}{l}0.74 \\
0.35 \\
0.66 \\
0.55 \\
0.86 \\
0.40 \\
0.55 \\
0.75 \\
0.68 \\
0.69 \\
0.61 \\
0.63 \\
0.66\end{array}$ \\
\hline $\mathrm{S} 2$ & 420 & $\mathrm{M}$ & $\begin{array}{c}1 \\
2 \\
3 \\
4 \\
5 \\
6 \\
7 \\
8 \\
9 \\
\text { Total }\end{array}$ & $\begin{array}{l}\text { 11-Apr-11 } \\
\text { 12-Apr-11 } \\
\text { 12-Apr-11 (night) } \\
\text { 13-Apr-11 } \\
\text { 18-Apr-11 } \\
\text { 19-Apr-11 } \\
\text { 23-Apr-11 } \\
\text { 10-May-11 } \\
\text { 11-May-11 (day/night/day) }\end{array}$ & $\begin{array}{r}10.3 \\
6.0 \\
6.0 \\
5.0 \\
2.5 \\
6.3 \\
6.0 \\
5.5 \\
26.4 \\
75.2\end{array}$ & $\begin{array}{r}4.60 \\
4.92 \\
3.44 \\
12.22 \\
2.59 \\
5.87 \\
7.41 \\
2.61 \\
29.00 \\
70.05\end{array}$ & $\begin{array}{r}0.07 \\
0.02 \\
2.17 \\
0.01 \\
0.89 \\
0.85 \\
0.42 \\
0.63 \\
6.77 \\
12.16\end{array}$ & . & . & $\begin{array}{l}0.06 \\
0.22 \\
0.09 \\
0.18 \\
0.00 \\
0.08 \\
0.03 \\
0.08 \\
0.18 \\
0.11\end{array}$ & $\begin{array}{l}0.29 \\
0.16 \\
0.56 \\
0.15 \\
0.60 \\
0.37 \\
0.53 \\
0.14 \\
0.14 \\
0.36\end{array}$ & $\begin{array}{l}0.59 \\
0.59 \\
0.80 \\
0.58 \\
0.80 \\
0.66 \\
0.62 \\
0.51 \\
0.76 \\
0.65\end{array}$ \\
\hline S3 & 350 & $\mathrm{M}$ & $\begin{array}{c}1 \\
2 \\
3 \\
\text { Total }\end{array}$ & $\begin{array}{l}\text { 15-May-11 } \\
\text { 16-May-11 } \\
21-M a y-11\end{array}$ & $\begin{array}{r}6.2 \\
6.3 \\
6 \\
18.5\end{array}$ & $\begin{array}{r}7.64 \\
14.62 \\
7.03 \\
29.29\end{array}$ & $\begin{array}{l}1.14 \\
5.62 \\
1.97 \\
6.03\end{array}$ & 3.15 & 0.16 & $\begin{array}{l}0.33 \\
0.63 \\
0.42 \\
0.46\end{array}$ & $\begin{array}{l}0.43 \\
0.63 \\
0.34 \\
0.48\end{array}$ & $\begin{array}{l}0.82 \\
0.84 \\
0.72 \\
0.79\end{array}$ \\
\hline S4 & 300 & $\mathrm{M}$ & $\begin{array}{c}1 \\
2 \\
\text { Total }\end{array}$ & $\begin{array}{l}\text { 15-Nov-11 (day/night) } \\
\text { 16-Nov-11 }\end{array}$ & $\begin{array}{r}11 \\
2 \\
13\end{array}$ & $\begin{array}{r}11.48 \\
3.43 \\
14.91\end{array}$ & $\begin{array}{l}1.60 \\
0.17 \\
1.84\end{array}$ & & & $\begin{array}{l}0.02 \\
0.02 \\
0.02\end{array}$ & $\begin{array}{l}0.46 \\
0.48 \\
0.46\end{array}$ & $\begin{array}{l}0.72 \\
0.88 \\
0.74\end{array}$ \\
\hline S5 & 450 & $\mathrm{M}$ & $\begin{array}{c}1 \\
2 \\
3 \\
4 \\
5 \\
6 \\
7 \\
8 \\
9 \\
10 \\
\text { Total }\end{array}$ & $\begin{array}{l}\text { 16-Feb-12 } \\
17-F e b-12 \\
20-F e b-12 \\
21-F e b-12 \\
26-F e b-12 \text { (night) } \\
27-F e b-12 \\
12-M a r-12 \\
13-M a r-12 \\
15-M a r-12 \\
21-M a r-12\end{array}$ & $\begin{array}{r}5 \\
5 \\
10 \\
4 \\
7 \\
3 \\
1 \\
7 \\
8 \\
8 \\
57.5\end{array}$ & $\begin{array}{r}9.79 \\
6.02 \\
11.78 \\
5.94 \\
13.02 \\
1.45 \\
1.18 \\
11.51 \\
8.86 \\
18.98 \\
88.53\end{array}$ & $\begin{array}{l}0.46 \\
0.11 \\
0.34 \\
0.11 \\
2.20 \\
0.05 \\
0.04 \\
0.14 \\
0.15 \\
1.60 \\
4.05\end{array}$ & 1.94 & 0.09 & $\begin{array}{l}0.34 \\
0.25 \\
0.33 \\
0.26 \\
0.11 \\
0.07 \\
0.29 \\
0.42 \\
0.40 \\
0.20 \\
0.27\end{array}$ & $\begin{array}{l}0.57 \\
0.33 \\
0.37 \\
0.39 \\
0.55 \\
0.21 \\
0.47 \\
0.50 \\
0.30 \\
0.74 \\
0.45\end{array}$ & $\begin{array}{l}0.70 \\
0.68 \\
0.65 \\
0.67 \\
0.84 \\
0.64 \\
0.52 \\
0.70 \\
0.63 \\
0.79 \\
0.69\end{array}$ \\
\hline
\end{tabular}




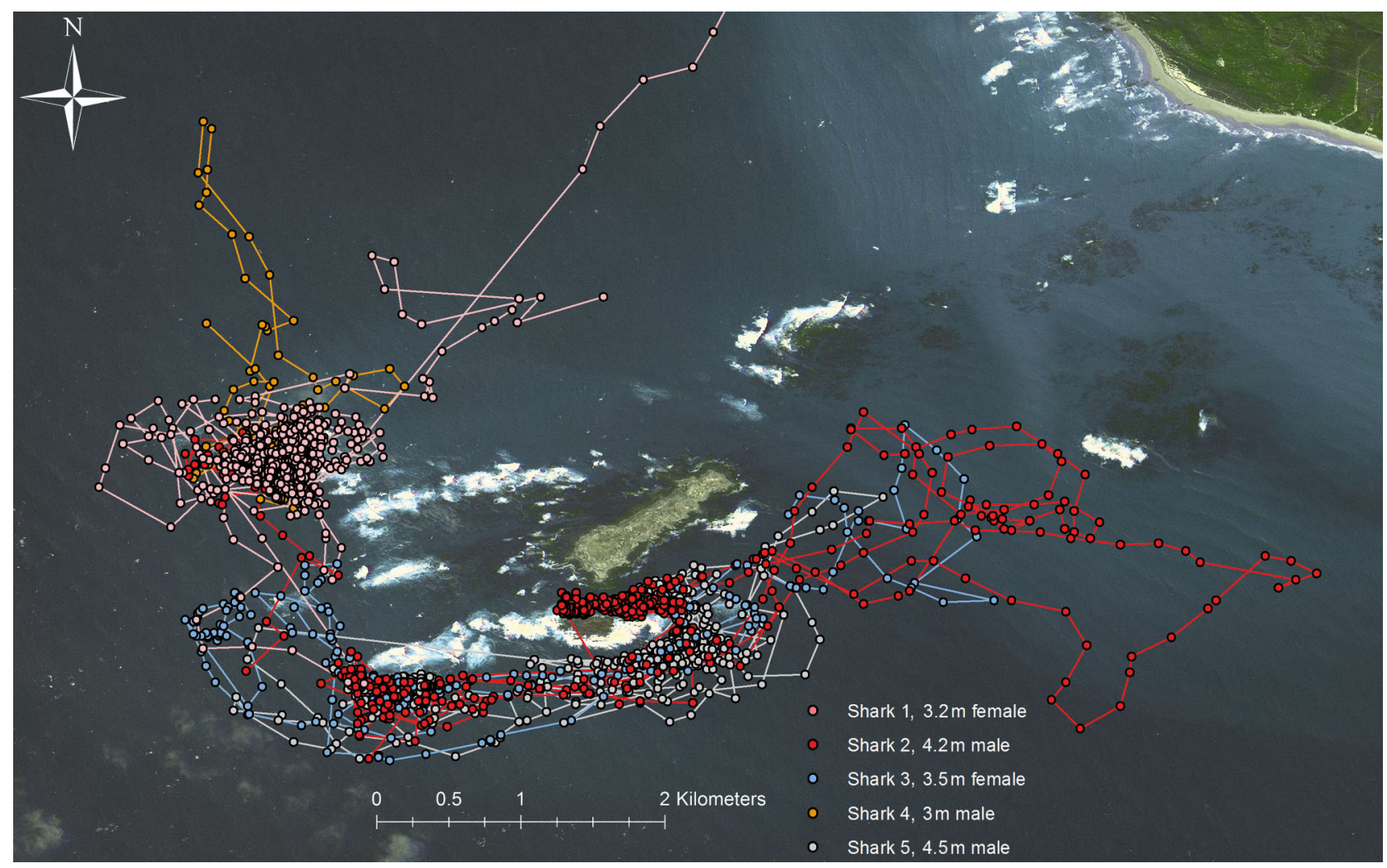

Fig. 2. Total tracking effort around Dyer Island. Shark 1 was tagged in the inshore reefs at Joubertsdam and moved to the Geldsteen within $4 \mathrm{~h}$, where it remained for the duration of its track. Sharks 2, 3, 4 and 5 were all tagged at Dyer Island

movements between areas but the majority of largerscale movements (activity areas $>1 \mathrm{~km}^{2}$ ) were made after nightfall. These movements included visits to distant $(>1 \mathrm{~km})$ reefs, back and forth movements offshore of Geyser Rock under strong moonlight and moving further offshore once the moon set, before returning to Shark Alley as daytime returned (Fig. 3). There was a significant relationship between the distance from Geyser Rock and the size (TL) of the shark during daytime (statistical interaction, $\mathrm{p}<0.001$ ): the larger the shark the closer to Geyser Rock it remained. During night all sharks moved further away.

ROM was significantly associated with distance from Geyser Rock (during daytime only) and with LI (distance $p=0.0074$, LI $p=0.0001$ ) but not with size $(p=0.6926)$. After correcting for the effect of day/night time and distance from Geyser Rock, for every unit LI increased, ROM increased at an estimated $39 \%(p<0.0001)$. The model did not find ROM to increase significantly at night ( $\mathrm{p}=0.8318)$ (Fig. 4); however, average ROM values were lower during daylight $\left(0.28 \mathrm{~m} \mathrm{~s}^{-1}\right)$ than at night $\left(0.75 \mathrm{~m} \mathrm{~s}^{-1}\right)$ (Fig. 5) and during daytime it increased with $14 \%$ for every $\mathrm{km}$ from Geyser Rock $(\mathrm{p}=0.0047)$.
LI was significantly associated with ROM, distance from Geyser Rock and whether it was day or night, but there was no significant relation to size or gender. LI increased significantly the further from Geyser Rock movements took place $(p=0.0468)$, the larger the ROM was $(p<0.0001)$ and was significantly higher at night than during daytime $(\mathrm{p}<$ 0.0001) (Fig. 4). Transformation was too complicated to back-transform for effect of size. Swimming depths were greater during night than daytime (8.81 m during daylight, $11.51 \mathrm{~m}$ during night), and activity areas displayed large variance from night to daytime but these results were not significantly different (Fig. 5). IOR and activity area were significantly different between individuals $(\mathrm{p}<0.0001)$, but were not determined by size $(p=0.8504)$. Daytime activity areas generally reached their plateaus within the first $40 \mathrm{~h}$ of tracking; the sharp rise in Shark 2's discovery curve after $60 \mathrm{~h}$ and the rise in Shark 5's discovery curve between 50 and $55 \mathrm{~h}$ were both recorded during night movements (Fig. 6).

Home range analysis was used to determine the site specific range and total activity area of 4 of the 5 sharks tracked (Shark 4's track contained too few 

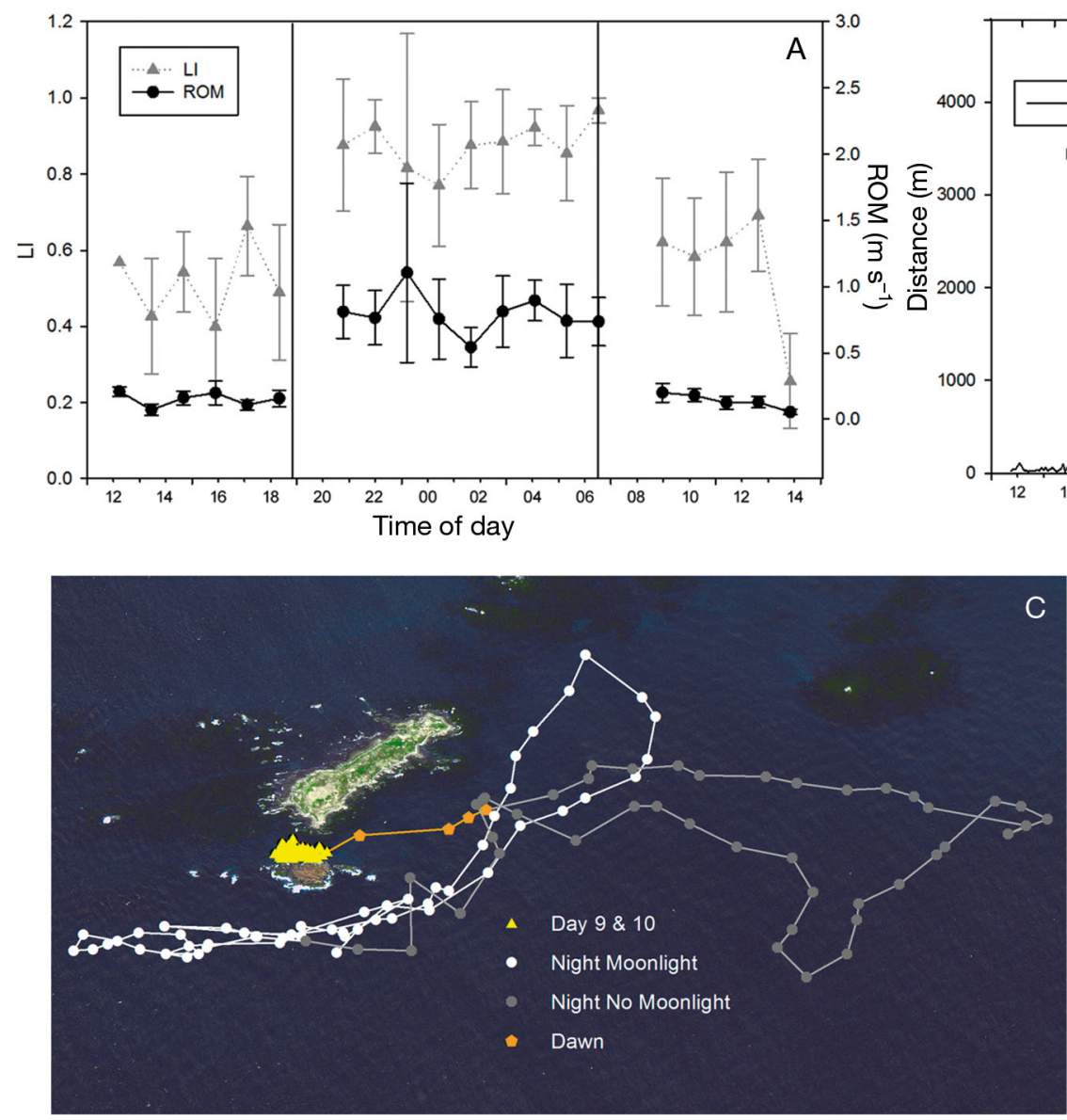

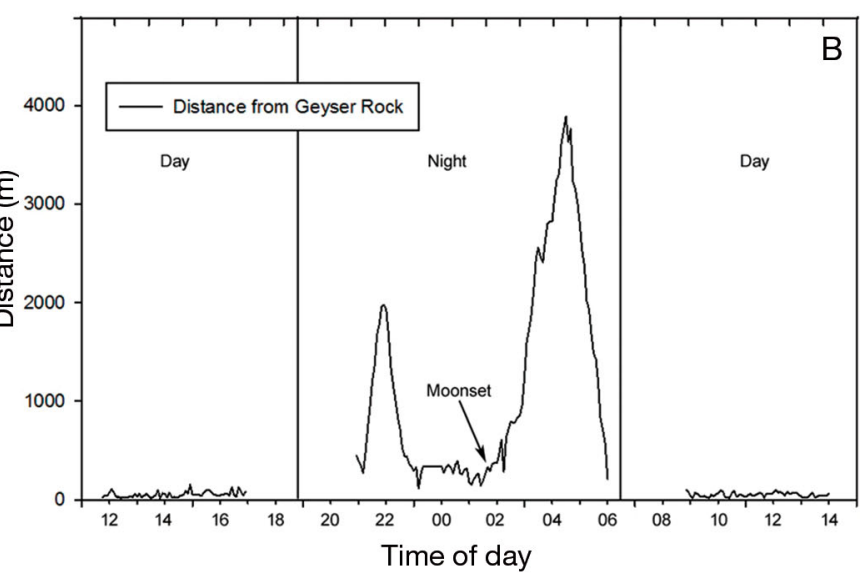

Fig. 3. Continuous track of Shark 2 over a 26.4 $\mathrm{h}$ period between Days 9 and 10 of tracking. (A) LI and ROM values per hour of tracking, both of which increased at night. (B) Distance from Geyser Rock, this initially increased after nightfall before the shark moved closer to Geyser Rock again until moonset when it moved away to a maximum distance of $3.9 \mathrm{~km}$. (C) Diel movements of the shark over the tracking period. As in previous daytime tracks, movement was limited to Shark Alley during daytime and further offshore at night. During strong moonlight, the shark made repeated back and forth movements to the south of Geyser Rock and after the moonset the shark moved east into deeper water before returning to forage in Shark Alley at dawn
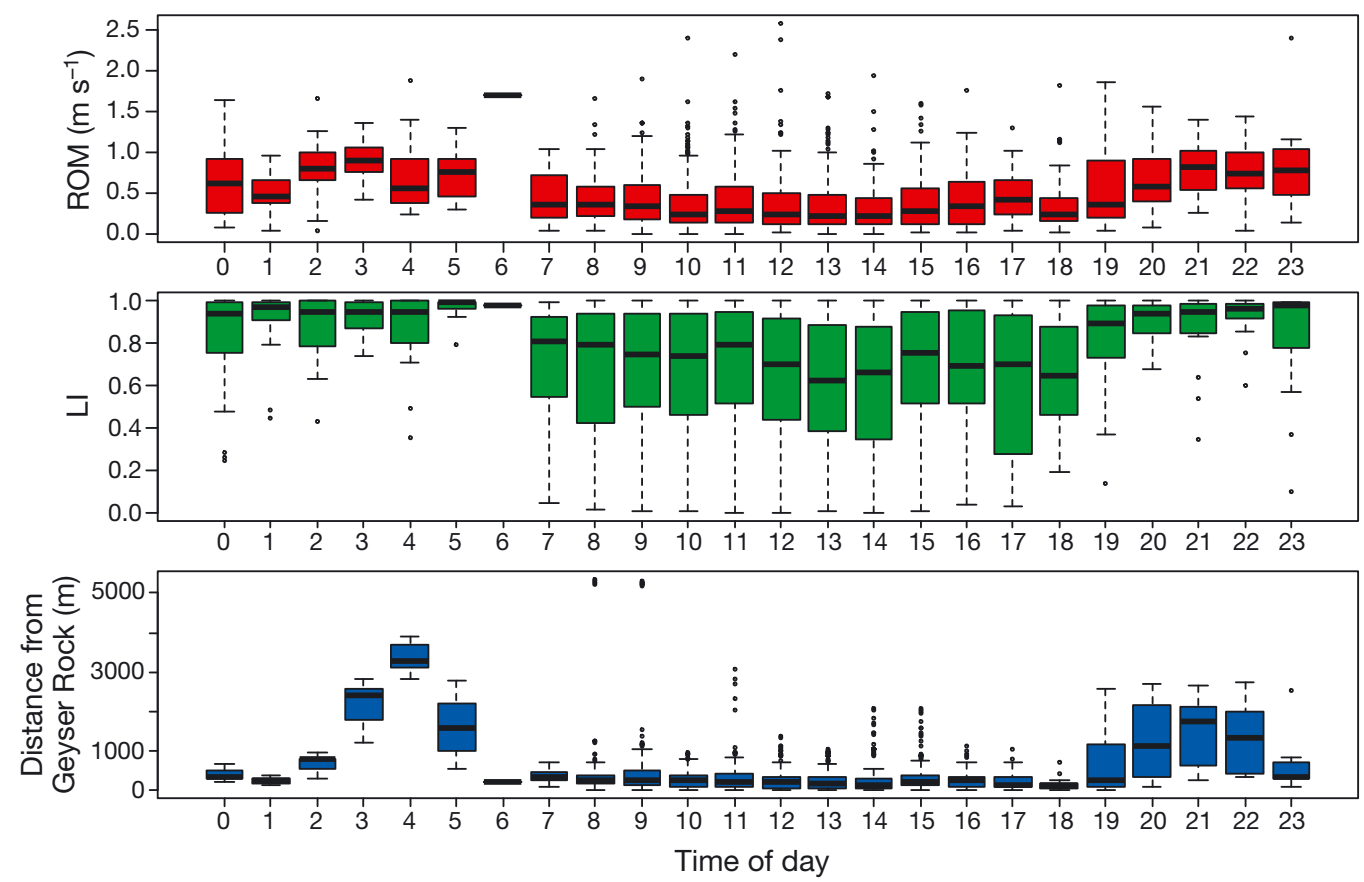

Fig. 4. Box plots for Rates of Movement (ROM), Linearity Index (LI) and distance from Geyser Rock for positions recorded at each hour of the day. Patterns followed movements with low ROM and LI close to Geyser Rock, Dyer Island or kelp forest during daytime before moving further away with higher ROM and LI during night 

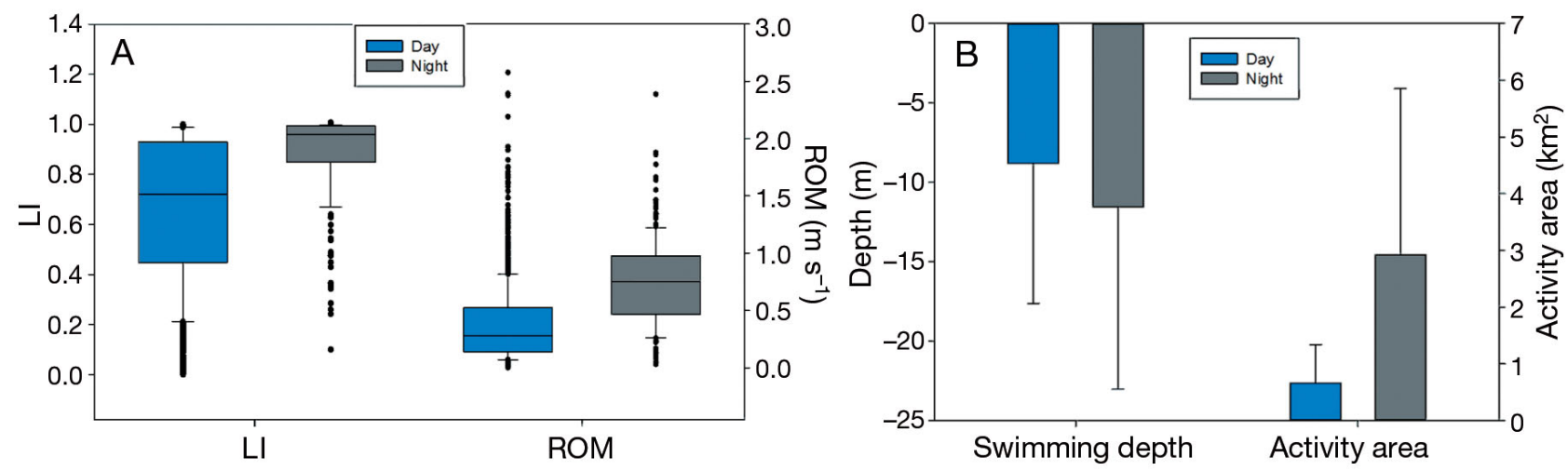

Fig. 5. (A) Mean LI and ROM values from day and night tracks. (B) Mean swimming depth and activity area values from day and night tracks

data points to compute MKDEs). Total activity areas (MCP) ranged from 4.05 to $12.16 \mathrm{~km}^{2}$ and showed no relation to size of individual or amount of hours tracked. Location-based kernel estimates, using LSCV smoothing parameters were focused around island locations, overlapped the boundaries formed by the landscape, and neglected migration routes. The lowest boundary overlap was recorded from Shark 1's LSCV UD, which was focused around the reef system to the northwest of Geyser Rock. The LSCV UDs from the other 3 sharks overlapped with large areas of the Geyser Rock system and Dyer Island (24 to $98 \%$ of Geyser Rock's total area, Fig. 7A). Shark 3's LSCV estimate was larger than the total area the shark used.

MKDEs incorporated more migration corridors between core areas of habitat use than LSCV estimates and did not smooth outside total activity areas or over barriers set around the Geyser Rock system,

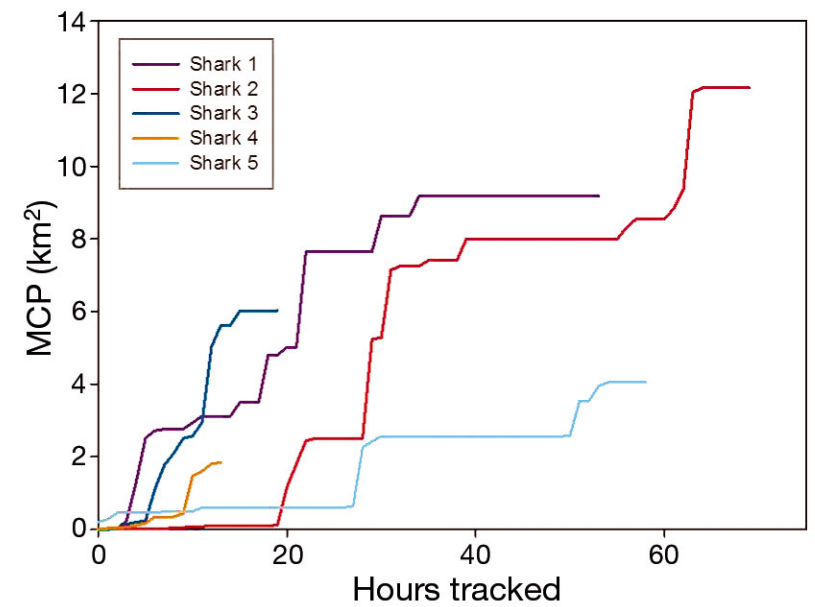

Fig. 6. Effect of duration of tracking on activity area (MCP) of cumulative shark tracks. Steep rises indicate movements into new areas whereas plateaus correspond to repeat use of an activity area
Dyer Island or the dense areas of kelp adjacent to them (Fig. 7B). MKDEs produced larger 95\% UD estimates than 3 of the LSCV estimates (Sharks 1, 2 and 5 ; Table 2), but the estimate for Shark 3 was under half $\left(3.15 \mathrm{~km}^{2}\right)$ that of the LSCV estimate $\left(6.71 \mathrm{~km}^{2}\right.$; Table 2$)$.

\section{DISCUSSION}

MKDEs have provided a suitable alternative to traditional methods of estimating home range. In this study, the MKDE's ability to account for barriers and include navigation routes between core areas of habitat use was particularly useful. It is likely that the method can be applied to similar studies utilising telemetry of marine life in coastal areas, particularly marine mammals and birds, which can be tracked above surface. A limiting factor that may arise when applying the methods to other fish telemetry data, particularly those not collected using similar methods, may be the spatial resolution or duration of subsurface tracks. Fish telemetry derived from Vemco Positioning System (VPS) type arrays of acoustic receivers have high spatial resolution, but tagged individuals may spend long periods of time outside the detection range of receivers (as in Currey et al. 2013, McLean et al. 2014). Animals tracked with Popup Archival Tags (PATs), however, traditionally produce tracks that have large degrees of error and poor spatial resolution (Teo et al. 2004), which would violate $t_{\max }$ (the largest time interval assumed to provide reliable movement information) parameters of the MKDE programme (Benhamou \& Cornélis 2010, Benhamou 2011). Accuracy in light-based geo-location processing is continually improving (Wildlife Computers pers. comm.) and in future may provide enough resolution to meet $t_{\max }$ requirements and 
Fig. 7. Utilisation Distributions (UDs) of 4 sharks tagged and tracked at Dyer Island using: (A) traditional location-based estimates derived from Least Square Cross Validation (LSCV) and 95\% (outer green) and 50\% (inner grey) isobars; yellow shaded areas represent overlap of UDs with areas of Geyser Rock, the peninsula extending from it, Dyer Island and thick areas of kelp at the Geldsteen; (B) Movementbased Kernel Density Estimates (MKDEs) with $95 \%$ (outer yellow) and $50 \%$ (inner red) isobars. S1 = Shark 1, S2 = Shark 2, etc. Shark 4 's tracking duration was too short for a UD estimate to be calculated
S1

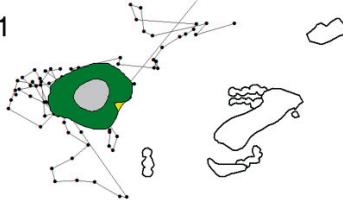

S2

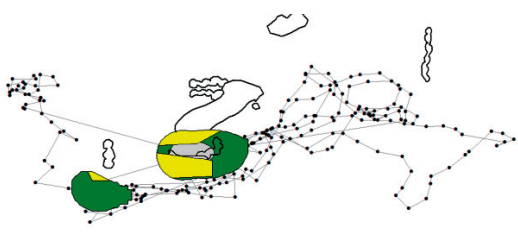

S3

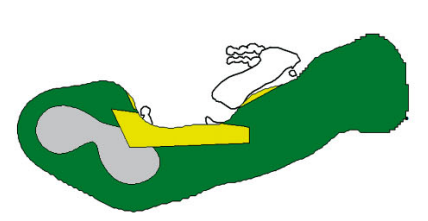

S5

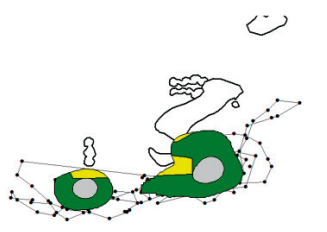

A

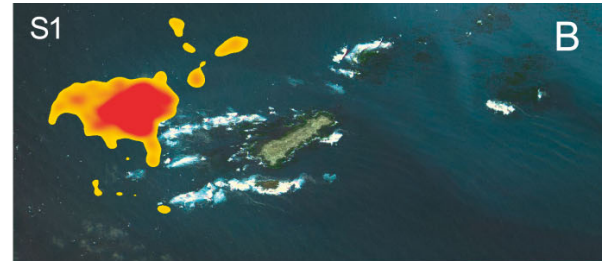

S2

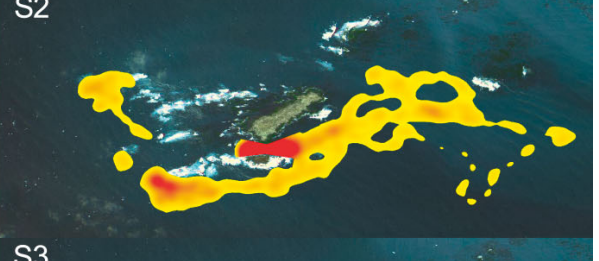

S3

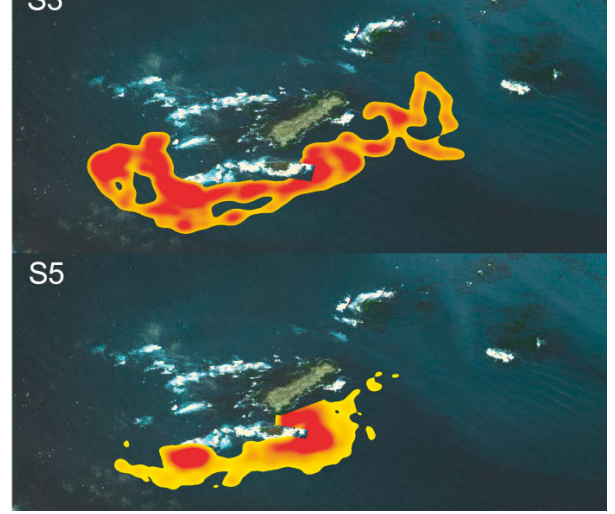

project MKDEs of archived tracks. An interesting challenge will be to apply the MKDE method to telemetry obtained from Smart Position Only Tags (SPOTs), which may transmit for several years and are capable of tracking large-scale migrations (Bonfil et al. 2005, Weng et al. 2005, Jewell et al. 2011, Domeier et al. 2012). However, SPOTs only transmit when the tag breaks the surface and satellite coverage is available in that area at that time. This means there can be long periods of time in-between successful transmissions and then several transmissions in quick succession. Weng et al. (2008) only used SPOT data from tags mounted on salmon sharks that had been working reliably for an average of $365 \mathrm{~d}$

Table 2. Site Specific Home Range estimates for 4 sharks tagged and tracked at Dyer Island, using Least Square Cross Validation (LSCV) location-based estimates and Movement-based Kernel Density Estimates (MKDEs)

\begin{tabular}{|lrcccc|}
\hline Shark ID & $\begin{array}{c}\text { Total } \\
\text { area } \\
\left(\mathrm{km}^{2}\right)\end{array}$ & $\begin{array}{c}\text { LSCV H } \\
\text { value }\end{array}$ & $\begin{array}{c}\text { LSCV } \\
\text { K 95 } \\
\left(\mathrm{km}^{2}\right)\end{array}$ & $\begin{array}{c}\text { Overlap w/ } \\
\text { barrier } \\
\left(\mathrm{km}^{2}\right)\end{array}$ & $\begin{array}{c}\text { MKDE } \\
95 \\
\left(\mathrm{~km}^{2}\right)\end{array}$ \\
\hline S1: $320 \mathrm{~cm}$ Female & 9.18 & 0.001570 & 0.792 & 0.059 & 1.68 \\
S2: $420 \mathrm{~cm}$ Male & 12.16 & 0.001938 & 1.093 & 0.351 & 2.48 \\
S3: $350 \mathrm{~cm}$ Male & 6.03 & 0.002981 & 6.711 & 0.625 & 3.15 \\
S5: $450 \mathrm{~cm}$ Male & 4.05 & 0.001478 & 1.306 & 0.122 & 1.94 \\
\hline
\end{tabular}

and filtered transmissions frequencies to one reading every 1 to $3 \mathrm{~d}$ to compute location-based kernel density estimates. It is likely that a similar solution can be found to allow MKDEs to be computed from shark tracks derived from SPOT tags (S. Benhamou pers. comm.). In a future study, we will attempt to apply MKDEs to a dataset being compiled from SPOT tagged white sharks in southern Africa.

At Dyer Island and Geyser Rock, 4 focal areas of white shark habitat use were identified using the MKDE $50 \%$ estimates: in Shark Alley, the southeast corner of Geyser Rock, the submerged peninsula to its west and the Geldsteen northwest of the seal colony (Fig. 6B). These focal areas correspond with Cape fur seal presence and seal movement corridors (M. Weisel, A. de Vos \& J. O'Riain unpubl.). LI values, swimming depths and distances from the Geyser Rock system all increased during the night as sharks moved into offshore areas (Table 1, Figs. 2-5). Sharks may move to deeper waters at night to pursue other sources of prey, i.e. cephalopods (Domeier 2012, Smale \& Cliff 2012) or teleosts and elasmobranchs (Carlisle et al. 2012, Hussey et al. 2012), as low and no 
light levels may prevent sharks from successfully hunting seals (Hammerschlag et al. 2006, Laroche et al. 2008). For example, Shark 2 remained close to the Geyser Rock system after sunset when there was strong ambient moonlight and moved offshore once the moon set (Fig. 3). Weng et al. (2007) found that juvenile white sharks in the eastern Pacific spent dawn, day, dusk and some moonlit hours at deeper depths than during the night, while Gleiss et al. (2013) found whale shark activity off Ningaloo Reef, Australia peaked at sunset and vertical activity peaked slightly before this. By using accelerometers, Gleiss et al. (2013) also distinguished foraging events from non-foraging events and confirmed that deil patterns in vertical habitat selection and movements do not necessarily reflect patterns in activity and foraging behaviour. Future work involving accelerometers and/or shark mounted video equipment could investigate whether the patterns observed in this study are directly related to foraging or other behaviours. Ambient light levels could also be assessed along with behavioural data (as in Hammerschlag et al. 2006), as cloud cover and fog could equally affect shark movements and habitat use in the same way daylight, night and moonlight appear to have in the current study.

The average UD of white sharks at Mossel Bay was larger $\left(12.21 \mathrm{~km}^{2}\right)$ than the average UD at Geyser Rock $\left(2.31 \mathrm{~km}^{2}\right.$ ) (Jewell et al. 2012, this study). Sharks at Mossel Bay spent the majority of day and night time hours in reef systems and moved close to the seal colony during the hours of dawn and dusk (Johnson et al. 2009). This differed from the swimming patterns at Dyer Island and Geyser Rock, where sharks spent the majority of daytime hours at or close to the Geyser Rock system, only moving to other areas at night. This difference may be attributed to varying age-classes, as sharks at Dyer Island and Geyser Rock are predominantly sub-adult to adults that primarily feed on marine mammals (Estrada et al. 2006, Ferrara et al. 2011, Towner et al. 2013). In contrast, sharks at Mossel Bay are predominantly juvenile to sub-adult that feed on teleost, cephalopod and other reef-based prey as well as marine mammals (Estrada et al. 2006, Johnson \& Kock 2006, Ferrara et al. 2011, Smale \& Cliff 2012). Interestingly, large sharks are also found inshore of Dyer Island and Geyser Rock, predominantly during summer months (Towner et al. 2013) and investigations here may reveal further variation of white shark habitat use between different areas (A. V. Towner \& O. J. D. Jewell unpubl. data). Average ROM and LI values were comparable between this study and
Johnson et al. (2009); however, ROM may have been underestimated in some areas of this study, as shark movements within Shark Alley were often at a finerscale than the 5 min sampling interval.

\section{CONCLUSIONS}

This study provides a suitable resolution to mapping habitat use of highly mobile animals within complex marine landscapes. MKDEs are particularly suited for analysing fine-scale tracking and would likely be useful in future marine-based studies using methods of acoustic or satellite telemetry. Furthermore, MKDE analysis of large-scale satellite data would highlight areas where fine-scale investigation is necessary without disregarding navigational routes within a species' home range. By comparing the swimming patterns of white sharks between 2 aggregation areas and finding substantial differences, we underscore that effective management plans must be developed from comprehensive arrays of fine-scale studies within a species' overall home range.

Acknowledgements. Thanks to those from the Dyer Island Conservation Trust, Marine Dynamics Shark Tours and Dyer Island Cruises who made this project possible: Mike Gibbs, Susan Visage, Brenda Walters, Alouise Lynch, Claudine O'Conner, Kira Matiwane, Warren Titus, Albert Scholtz, Pieter du Toit and all the visitors who donated towards this cause. Thanks to VW South Africa for continued support of the DICT and sponsoring the fuel budget. A National Lottery grant was provided for tags, Malcolm Smale of Bayworld lent equipment and the Department of Environmental Affairs permitted the research. Thanks to Dicky Chivell, Nick Jones and David Edwards for extended assistance in the field, as well as Nicola Stelluto, Matt Nicholson and the volunteers and interns working with Marine Dynamics. Thanks to Ellie MacLeannan and Tami Kaschke for assistance in data processing and Simon Benhamou for troubleshooting with Pascal and Arc GIS projections. The background satellite imagery was provided by Ian Kootze of Agri GIS. Thanks also to the Gansbaai community for their support of white shark research. Final thanks to the anonymous reviewers who helped improve this work and the Overstrand Medical Response team for fixing O.J.'s dislocated shoulder in Kleinbaai harbour when tracking went wrong!

\section{LITERATURE CITED}

Anderson SD, Chapple TK, Jorgensen SJ, Klimely AP, Block BA (2011) Long-term individual identification and site fidelity of white sharks, Carcharodon carcharias, off California using dorsal fins. Mar Biol 158:1233-1237

> Benhamou S (2011) Dynamic approach to space and habitat use based on biased random bridges. PLoS ONE 6:e14592

> Benhamou S, Cornélis D (2010) Incorporating movement behavior and barriers to improve kernel home range space use estimates. J Wildl Manag 74:1353-1360 
Benhamou S, Riotte-Lambert L (2012) Beyond the Utilization Distribution: identifying home range areas that are intensively exploited or repeatedly visited. Ecol Modell 227:112-116

> Block BA (2005) Physiological ecology in the 21st Century: advancements in biologging science. Integr Comp Biol 45:305-320

> Block BA, Jonsen ID, Jorgensen SJ, Winship AJ and others (2011) Tracking apex marine predators in a dynamic ocean. Nature 475:86-90

Bonfil R, Meÿer M, Scholl MC, Johnson R and others (2005) Transoceanic migration, spatial dynamics, and population linkages of white sharks. Science 310:100-103

Bruce BD (1992) Preliminary observations on the biology of the white shark, Carcharodon carcharias, in South Australian waters. Aust J Mar Freshwat Res 43:1-11

Burt WH (1943) Territoriality and home range concepts as applied to mammals. J Mammal 24:346-352

Carlisle AB, Kim SL, Semmens BX, Madigan DJ and others (2012) Using stable isotope analysis to understand the migration and trophic ecology of northeastern Pacific white sharks (Carcharodon carcharias). PLoS ONE 7: e30492

Cornélis D, Benhamou S, Janeau G, Morellet N, Ouedraogo M, de Visscher MN (2011) Spatiotemporal dynamics of forage and water resources shape space use of West African Savanna buffalo. J Mammal 92:1287-1297

Currey LM, Heupel MR, Simpfendorfer CA (2013) Stay or stray: examination of reef-based movement of redthroat emperor. Presentation: 2nd International Conf on Fish Telemetry. Grahamstown, 14-19 July 2013

> Da Silva C, Kerwath SE, Atwood CG, Thorstad EB and others (2013) Quantifying the degree of protection afforded by a no-take marine reserve on an exploited shark. Afr J Mar Sci 35:57-66

Domeier ML, Nasby-Lucas N, Lam CH (2012) Fine-scale habitat use by white sharks at Guadalupe Island, Mexico. In: Domeier ML (ed) Global perspectives on the biology and life history of the white shark. CRC Press, Boca Raton, FL, p 121-131

Domeier ML (ed) (2012) A new life history hypothesis for white sharks in the northeastern Pacific. In: Global perspectives on the biology and life history of the white shark. CRC Press, Boca Raton, FL, p 199-223

> Dulvy NK, Baum JK, Clarke S, Compagno LJV and others (2008) You can swim but you can't hide: the global status and conservation of oceanic pelagic sharks and rays. Aqua Cons Mar Freshwat Ecosyst 18:459-482

Estrada JA, Rice AN, Natanson LJ, Skomal GB (2006) Use of isotopic analysis of vertebrae in reconstructing ontogenetic feeding ecology in white sharks. Ecology 87: 829-834

Ferrara TL, Clausen P, Huber DR, McHenry CR, Peddemors V, Wroe S (2011) Mechanics of biting in great white and sandtiger sharks. J Biomech 44:430-435

Ferreira C, Ferreira TP (1996) Population dynamics of white sharks in South Africa. In: Klimley AP, Ainley DG (eds) Great white sharks: the biology of Carcharodon carcharias. Academic Press, San Diego, CA, p 381-391

> Gleiss AC, Wright S, Liebsch N, Wilson RP, Norman B (2013) Contrasting diel patterns in vertical movement and locomotor activity of whale sharks at Ningaloo Reef. Mar Biol 160:2981-2992

Goldman KJ, Anderson SD (1999) Space utilization and swimming depth of white shark (Carcharodon carcha- rias) at the South Farallon Islands, central California. Environ Biol Fishes 56:351-364

Hammerschlag N, Martin RA, Fallows C (2006) Effects of environmental conditions on predator-prey interactions between white sharks (Carcharodon carcharias) and Cape fur seals (Arctocephalus pusillus pusillus) at Seal Island, South Africa. Environ Biol Fishes 76:341-350

- Hammerschlag N, Gallagher AJ, Wester J, Luo J, Ault JS (2012) Don't bite the hand that feeds: assessing ecological impacts of provisioning ecotourism on an apex marine predator. Funct Ecol 26:567-576

> Hearn A, Ketchum J, Klimley AP, Espinoza E, Penaherrera C (2010) Hotspots within hotspots? Hammerhead shark movements around Wolf Island, Galapagos Marine Reserve. Mar Biol 157:1899-1915

Heithaus MR, Dill LM, Marshall GJ, Buhleire B (2002) Habitat use and foraging behavior of tiger sharks (Galeocerdo cuvier) in a seagrass ecosystem. Mar Biol 140:237-248

Heupel MR, Simpfendorfer CA, Hueter RE (2004) Estimation of shark home ranges using passive monitoring techniques. Environ Biol Fishes 71:135-142

> Heupel MR, Yeiser BG, Collins AB, Ortega L, Simpfendorfer CA (2010) Long-term presence and movement patterns of juvenile bull sharks, Carcharhinus leucas, in an estuarine river system. Mar Freshw Res 61:1-10

Hussey NE, McCann HM, Cliff G, Dudley S, Wintner SP, Fisk AT (2012) Size-based analysis of diet and trophic position of the white shark, Carcharodon carcharias, in South African waters. In: Domeier ML (ed) Global perspectives on the biology and life history of the white shark. CRC Press, Boca Raton, FL, p 27-49

Jewell OJD (2013) Foraging ecology of white sharks Carcharodon carcharias at Dyer Island, South Africa. MSc thesis, University of Pretoria

> Jewell OJD, Wcisel MA, Gennari E, Towner AV, Bester MN, Johnson RL, Singh S (2011) Effects of Smart Position Only (SPOT) tag deployment on white sharks in South Africa. PLoS ONE 6:e27242

Jewell OJD, Johnson RL, Gennari E, Bester M (2012) Fine scale movement patterns and activity areas of white sharks (Carcharodon carcharias) at Mossel Bay, South Africa. Environ Biol Fishes 96:881-894

Johnson R, Kock A (2006) South Africa's white shark cagediving industry - is there cause for concern? In Nel DC, Peschak TP (eds) Finding a balance: white shark conservation and recreational safety in the inshore waters of Cape Town, South Africa; proceedings of a specialist workshop. WWF South Africa Report Series - 2006/Marine/001

Johnson R, Bester MN, Dudley SFJ, Oosthuizen WH, Meÿer M, Hancke L, Gennari E (2009) Coastal swimming patterns of white sharks (Carcharodon carcharias) at Mossel Bay, South Africa. Environ Biol Fishes 85:189-200

Klimley AP, Le Boeuf BJ, Cantara KM, Richert JE and others (2001) The hunting strategy of white sharks (Carcharodon carcharias) near a seal colony. Mar Biol 138:617-636

Kock A, O'Riain MJ, Mauff K, Meÿer M, Kotze D, Griffiths C (2013) Residency, habitat use and sexual segregation of white sharks, Carcharodon carcharias in False Bay, South Africa. PLoS ONE 8:e55048

> Laroche RK, Kock AA, Dill LM, Oosthuizen WH (2008) Running the gauntlet: a predator-prey game between sharks and two age classes of seals. Anim Behav 76:1901-1917

McLean MF, Simpfendorfer CA, Heupel MR, Dadswell MJ, Stokesbury MJW (2014) Diversity of behavioural pat- 
terns displayed by a summer feeding aggregation of Atlantic sturgeon in the intertidal region of Minas Basin, Bay of Fundy, Canada. Mar Ecol Prog Ser 496:59-69

McNab BK (1963) Bioenergetics and the determination of home range size. Am Nat 97:133-140

Meyer CG, Holland KN (2005) Movement patterns, home range size and habitat utilization of the bluespine unicornfish, Naso unicornis (Acanthuridae) in a Hawaiian marine reserve. Environ Biol Fishes 73:201-210

Myers RA, Baum JK, Shepherd TD, Powers SP, Peterson CH (2007) Cascading effects of the loss of apex predatory sharks from a coastal ocean. Science 315:1846-1850

Revuelta O, Leon YM, Feliz P, Godley BJ, Raga JA, Tomas J (2012) Protected areas host important remnants of marine turtle nesting stocks in the Dominican Republic. Oryx 46:348-358

Simpfendorfer CA, Wiley TA, Yeiser BG (2010) Improving conservation planning for an endangered sawfish using data from acoustic telemetry. Biol Conserv 143:1460-1469

Smale MJ, Cliff G (2012) White sharks and cephalopod prey: indicators of habitat use? In: Domeier ML (ed) Global perspectives on the biology and life history of the white shark. CRC Press, Boca Raton, FL, p 51-59

Speed CW, Field IC, Meekan MG, Bradshaw CJA (2010) Complexities of coastal shark movements and their implications for management. Mar Ecol Prog Ser 408: 275-293

Strong WR, Murphy RC, Bruce BD, Nelson DR (1992) Movements and associated observations of bait-attracted white sharks Carcharodon carcharias: a preliminary report. Aust J Mar Freshwater Res 43:13-20

Teo SLH, Boustany A, Blackwell S, Walli A, Weng KC, Block

Editorial responsibility: Rory Wilson,

Swansea, UK
BA (2004) Validation of geolocation estimates based on light level and sea surface temperature from electronic tags. Mar Ecol Prog Ser 283:81-98

Towner AV, Wcisel MA, Reisinger RR, Edwards D, Jewell OJD (2013) Gauging the threat: the first population estimate for white sharks in South Africa using photo identification and automated software. PLoS ONE 8:e66035

> Voegeli FA, Smale MJ, Webber DM, Andrade Y, O'Dor RK (2001) Ultrasonic telemetry, tracking and automated monitoring technology for sharks. Environ Biol Fishes 60: 267-281

Wcisel MA (2013) The effects white shark presence has on the behaviour of Cape fur Seals at Geyser Rock, South Africa. MSc thesis, University of Cape Town

> Weng KC, Castilho PC, Morrissette JM, Landeira-Fernandez AM and others (2005) Satellite tagging and cardiac physiology reveal niche expansion in salmon sharks. Science 310:104-106

Weng KC, O'Sullivan JB, Lowe CG, Winkler CE, Dewar H, Block BA (2007) Movements, behaviour and habitat preferences of juvenile white sharks Carcharodon carcharias in the eastern Pacific. Mar Ecol Prog Ser 338:211-224

> Weng KC, Foley DG, Ganong JE, Perle C, Shillinger GL, Block BA (2008) Migration of an upper trophic level predator, the salmon shark Lamna ditropis, between distant ecoregions. Mar Ecol Prog Ser 372:253-264

> Worm B, Davis B, Kettermer L, Ward-Paige CA and others (2013) Global catches, exploitation rates, and rebuilding options for sharks. Mar Policy 40:194-204

> Worton BJ (1989) Kernel methods for estimating the utilization distribution in 397 home range studies. Ecology 70 : 164-168

Submitted: October 15, 2013; Accepted: April 4, 2014 Proofs received from author(s): June 11, 2014 